\title{
On The WH Question Particle [Wo] In Yorùbà
}

\author{
Timothy Adeyemi Akanbi \\ Department of Linguistics and Nigerian Languages, \\ Ekiti State University, Ado-Ekiti
}

doi: 10.19044/esj.2016.v12n17p414 URL:http://dx.doi.org/10.19044/esj.2016.v12n17p414

\begin{abstract}
Every language has markers which are used in order to turn a positive sentence to an interrogative one; and native speakers of such language know the appropriate marker to use in any particular structure in order to ask questions or elicit information. Many of the WH question markers in Yorùbá are composed of one word. However, the question particle ...wo 'when/which ${ }^{36}$ ' which is the focus of this paper, appears to be different in that it is composed of more than one word in its occurrence before it can function as a WH question marker. The focus of this paper is on this particular WH question particle (...wo) in Yorùbá. I argue that this particle is composed of more than one word before it can function as a question marker and turn a positive sentence to an interrogative one. In other words it must combine with either a prepositional phrase (PP) or a noun phrase (NP) and thereafter move to Spec-CP through movement rule of internal merge to check its WH interrogative feature for proper convergence at Spell-Out.
\end{abstract}

Keywords: Speakers, Internal Merge, Feature, Interrogative, Spell-Out

\section{Introduction}

Attempts have been made by scholars of linguistics to study and write on the interrogatives in various languages. Through their various

${ }^{36}$ This paper emanated and is based on the author's personal communication with Prof. Abiodun of the Linguistics Department, Ekiti State University. Prof. Abiodun believes that wo underlined, and rendered in bold face, is the question marker in structures like the ones below:

$$
\begin{array}{ll}
\text { Ní ìgbà wo ni Òjó dé? } & \text { 'When did Òjó arrive/return? } \\
\text { Ní ojộ wo ni Òjó dé? } & \text { 'Which day did Òjó arrive/return?' } \\
\text { Ní ọ̣ệ wo ni Òjó dé? } & \text { 'Which week did Òjó arrive/return?’ } \\
\text { Ní ọdún wo ni Òjó dé? } & \text { 'Which year did Òjó arrive/return?’ }
\end{array}
$$

This writer believes that it is the whole prepositional phrase (and the noun phrase, as will be shown in this paper) inclusive of wo that should be regarded as the question marker and is the question phrase. 
writings, it has been shown that there is no language that does not operate questions in its repertoire which is an indication that interrogation is part of Universal Grammar (UG) features. It has also been shown that there are markers present in every language which are used to turn a positive statement to an interrogative one. In every language, two types of question formations are attested; Yes/No or Polar question and WH or content question. Yes/No questions require just a yes or no answer while content questions require more than a yes or no. In fact in answer to a content question, a yes or no answer will be anomalous.

Just like any other language, Yorùbá has a way of forming questions; be it polar or content question. The markers or phrases used for each of these types of question formations are different. While polar question uses about four different markers, listed in (1), content questions have various markers listed in (2).

$1 \quad$ Polar question markers

(i) Njeẹ

(ii) Șé

(iii) Ha...bi

(iv) Șebí or Șèbí

2 Content question markers

$\begin{array}{lll}\text { (i) } & \text { Ta } & \text { 'who' } \\ \text { (ii) } & \text { Kí } & \text { 'what' } \\ \text { (iii) } & \text { (N)ibó } & \text { 'where' } \\ \text { (iv) } & \text { Èló } & \text { 'how much' } \\ \text { (v) } & \text { Mélòó } & \text { 'how many' } \\ \text { (vi) } & \text { Báwo } & \text { 'how' } \\ \text { (vii) } & \text { Kílódé } & \text { 'why' } \\ \text { (viii) } & \text {...wo } & \text { 'when/which' }\end{array}$

It needs be said that why the polar question markers are not sensitive to [ \pm human], the same cannot be said of content question markers; they have distinctive features that set them apart from each other. In other words, all of them cannot occur in the same syntactic position. There are, therefore, distinctive features that set each marker apart from the other. For instance $\mathrm{Ta}$ 'who' has the feature [+human], kí 'what' has the feature [ \pm animate], báwo 'how' has the feature [+manner], etc.

In discussing the issue of question marker/phrase in this paper, we divide the paper into four sections. Section one is the introduction. We present the theoretical framework for the study in section two. Section three is dedicated to the derivation of interrogative sentences in Yorùbá with emphasis on the question marker/phrase ...wo. Section four concludes the paper. 


\section{Theoretical Framework}

The theoretical framework adopted for this work is the Minimalist Program (MP). Minimalist Program, as propounded by Chomsky (1993, 1995, 1998, and 2000) and others like Zwart (1993) assumes that every clause formation starts with the selection of lexical items contained within the lexicon (Operation Select). Every word within the lexicon is believed to possess three universal sets of features which are <Sem, Syn, Phon> i.e. Semantic, Syntactic and Phonetic features. Syntactic derivation is formed by a simple mathematical operation called Merge. Merge is an operation which combines words selected from the lexicon with an already formed constituents or syntactic objects. Operation merge can be internal or external. It is known as external Merge when the operation combines words selected directly from the lexicon with an already formed constituents or syntactic objects; while it is known as Internal Merge when it recombines constituents within an already formed syntactic object. These and other operations such as Attract and merge within the MP are based on binary principle. Based on this, every operation of the type $\boldsymbol{x}, \boldsymbol{y}$ is the set of elements that includes $\boldsymbol{x}$ and $\boldsymbol{y}$. It means then that the binary nature of merge rules out ternary branching. MP ensures that the output of a syntactic derivation is not an arbitrary set but is derived from the input labels. For instance, the product of merge $(\alpha, \beta)$ can only be either an $\alpha$-phrase or a $\beta$ phrase but not $\gamma$-phrase since $\gamma$ was not part of the input in the first place (cf. Ilori and Oyebade 2012).

In MP, it is also assumed that every product of operation merge moves towards the interface level for Spell-Out. Spell-Out therefore, is the output of derivation at the level of pronunciation; i.e. Phonetic Form (PF). MP also ensures that every syntactic derivation converges at Spell-Out based on the compatibility of features of words employed in the derivation which must be checked against one another in the course of the process of derivation; otherwise, the derivation crashes.

Other MP assumptions, some of which, of course, are carry-overs from Government and Binding Theory (Chomsky 1981, 1986) are the SplitIP Hypothesis of Pollock (1989), and Split-CP Hypothesis of Rizzi (1997), which assume the splitting of the IP and CP projections into units within them in order to accommodate other elements that could move with the head in the process of Internal Merge. However, our analyses in this paper will make use of the IP and CP projections. The reason is because Split-CP of Rizzi (1997) is still controversial (see Newmeyer 2003b). 


\section{Formation of interrogative sentence in Yorùbá}

The question markers/phrases listed in (2) above are used in the various sentences below (The question markers are rendered in bold face in each example).

3

(a)

Ta ni Òjó rí?
QM FOC Ojo see
Who did Ojo see?

(b) Ta ni ó rí Òjó?

QM FOC RP see Ojo

Who saw Òjó?

$4 \quad$ Kí ní Adé mú wá?

QM FOC Adé take come

What did Adé bring?

5 (N)íbo ni Șadé ń lọ?

QM FOC Șadé PROG go

Where is Șadé going?

$6 \quad$ Èló ni ișu?

QM FOC yam

How much is the yam?

7. Ilé mélòó ni Bọ́lá kọ́?

House QM FOC Bola build

How many houses did Bọ́lá build?

8. Báwo ni ajá șe kú?

QM FOC dog do die

How did the dog die?

9. Kílódé tí Péjú lọ?

QM Ptcl. Peju go

Why did Peju go?

10. Nigba (Ni ìgbà) wo ni Kúnle dé?

PP period QP FOC Kunle arrive

When did Kunle arrive/return?

It could be observed that in the various sentences above the question marker occupies the initial position in each sentence except (7) and (10) ${ }^{37}$ where ișu 'yam' a noun, precedes the question marker and wo, a question particle follows the preposition phrase (PP). However, there is a way to paraphrase the sentence in (7) and make the question marker appear at the initial position as seen in (11), though a little modification has to come in by inserting the particle $t i$ within the sentence.

\footnotetext{
${ }^{37}$ The marker in (10) is the focus of this paper. Therefore, more will be said on it in the sub-
} sections below. 
11 Mélòó ni ilé tí Bộlá kọ́?

QM FOC house Prtc. Bọ́lá build

How many houses did Bola build?

The question to be asked and answered here is; what is the strategy of deriving the $\mathrm{WH}$ questions. This question is addressed in the following section.

\section{The derivation of WH question in Yorùbá}

Virtually all the WH questions in Yorùbá are derived by fronting the WH marker. Through the movement rule of internal merge, the WH element is moved from its originating position to the Spec-CP. The Spec-CP, which is an empty position, is the already prepared landing site for the $\mathrm{WH}$ element. Spec-CP is a position for element with the feature $[+\mathrm{N}]$; therefore, almost all the WH items in Yorùbá are of the feature $[+\mathrm{N}]$. This is so because the underlying form of many of these WH items before they became a WH item is originally a noun ${ }^{38}$. We shall illustrate this from the data below.

12

(a) Adé jẹ ișu

$\left.\begin{array}{l}\text { Adé eat yam } \\ \text { Ade ate yam }\end{array}\right\}$ Basic/underlying clause

(b) Adé jẹ kí?

Adé eat $W h$

Derived clause with WH word

question)

Ade ate what?

(c) Kín ni Adé jẹ ti ?

$\left.\begin{array}{l}\text { QM FOC Adé eat } \\ \text { What }_{\mathrm{i}} \text { did Ade eat } \mathrm{t}_{\mathrm{i}} \text { ? }\end{array}\right\}$ Interrogative sentence

The data in (12) above is the history of the derivation of $\mathrm{WH}$ questions in Yorùbá. This derivational history applies to virtually all the WH interrogative sentences in the language. As indicated beside each of the derivations, (12a) is the basic clause and the underlying form for the sentences in (12b) and (12c); we have the derived clause in (12b) with the noun isu 'yam' turning to a WH item kí 'what'. What we have in (12b) is what is called echo question in the literature. We have the spell-out form of the whole derivation in (12c). Here, the movement has taken place. In this instance, two operations come into play; they are attract and merge. The Spec-CP attracts the WH element in (12b) in order to satisfy its own feature

38 The only exception here are kílódé 'why' and báwo 'how' which can be regarded as adverbs. 
by checking its $\mathrm{WH}$ feature upon $\mathrm{C}$ of $\mathrm{CP}$ and then merges with the already formed structure. It is important to note that the movement in WH question formation in Yorùbá is effected before Spell-out otherwise; the derivation will not converge.

The issue of WH movement cuts across all WH questions in Yorùbá. The reason is because, unlike some languages, Yorùbá does not operate WH in-situ in the derivation of WH questions. In the next section, I discuss the issue of ...wo as question marker in Yorùbá.

\section{...wo as WH question marker/phrase in Yorùbá}

We present the following examples upon which our discussion in this section is based.

13

(a) Ní ìgbà (Nigba) wo ni Òjó dé?

Prep time/period QP FOC Òjó arrive

When did Òjó arrive/return?

(Litt. At which/what time did Òjó arrive?)

(b) Ní ojọ́ wo ni Òjó dé?

Prep day QP FOC Òjó arrive

Which/what day did Òjó arrive/return?

(c) Ní ọ̀sẹ̀ wo ni Òjó dé?

Prep. Week QP FOC Òjó arrive

Which/what week did Ójó arrive/return?

(d) Ní ọdún wo ni Òjó dé?

Prep. Year QP FOC Òjó arrive

Which/what year did Ójó arrive/return?

14 (a) İwé wo ni Olú rà?

Book QP FOC Olú buy

Which/what book did Olu buy?

(b) Ilé wo ni Olú kọ́?

House QP FOC Olú buy

Which/what house did Olu build?

(c) Aṣọ wo ni Bọ́lá wọ̀?

Cloth QP FOC Olú Bọ́lá wear

Which/what cloth did Bọlá wear?

It has been argued that in structures like those in (13) and (14) above, the WH question marker there is wo (Personal communication with Prof. Abiodun). We do not agree with this assertion, rather, we believe (and we shall argue in support of this belief) that the totality of the whole prepositional phrase or noun phrase, as the case may be, should be regarded, and is regarded, as the question marker; hence, our convention of writing this WH question marker as ...wo (a kind of $x$ wo where $x$ can either be a prepositional phrase or a noun phrase or any other phrase for that matter). 
The implication of our assertion here is that instead of having just an item as the WH question marker, in structures where wo occurs, we have a phrase that serves as the question marker. Our arguments in support of this assertion are presented in the sub-sections below.

\section{The inability of wo not being able to move independent of the PP or NP}

As we have earlier said, the derivation of WH question in Yorùbá involves turning the NP in the subject, the object or the adjunct position to a WH element and moving it to the Spec-CP of the whole sentence through the process of internal merge (see the examples in 12 above). This WH element that is moved leaves a copy of itself at the originating site; this copy represented by $t$ is co-indexed with the moved WH item at the Spec CP position which is the landing site as shown in (15) below.

15

(b) Ta $\quad \mathrm{Ta}_{\mathrm{i}}$ ni ó $\mathrm{o}_{\mathrm{i}}$ rí Adé?

$\mathrm{Ta}_{\mathrm{i}}$ ní Òjó rí $t_{i}$ ?

QM FOC Òjó see

Who $\mathrm{i}_{\mathrm{i}}$ did Òjó see $t_{i}$

QM FOC see Adé

Who saw Adé?

(c) (N)íbo ${ }_{i}$ ní Olú ti rí Adé $t_{i}$ ?

QM FOC Olú Ptcl see Adé

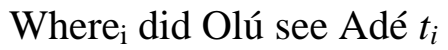

In (15a), the movement is from the object position; it is from the subject position in (15b), while the movement is from the adjunct position in (15c). In (15b), where the movement is from the subject position, a resumptive pronoun ó (which some scholars like Awobuluyi ${ }^{39}$ designate as High Tone Syllable (HTS)) is inserted. The reason for this is because (i) Yorùbá language does not tolerate leaving its subject position empty and (ii), the sentence will not converge without the insertion ó, hence, the sentence crashes after spell-out. In the language of Government and Binding (GB) theory (Chomsky 1981), the ó is inserted for proper government (cf. Sonaiya 1988). In the case of (15c), the originating site for the moved item is the adjunct position. When a movement is from the adjunct position in Yorùbá, the insertion of $t i$ designated as particle ${ }^{40}$ is obligatory without which the sentence fails to converge. We show the tree configuration of the structure in (15a) in (16) below.

\footnotetext{
${ }^{39}$ See Awobuluyi $(2001,2006)$ for his arguments on this issue

${ }^{40}$ Readers are referred to Sonaiya (1988), Ajiboye (2005) for the argument on why this [ti] must be inserted. They also argue on the function of this particle [ti]. Repeating their various arguments here in this paper will amount to tautology.
} 


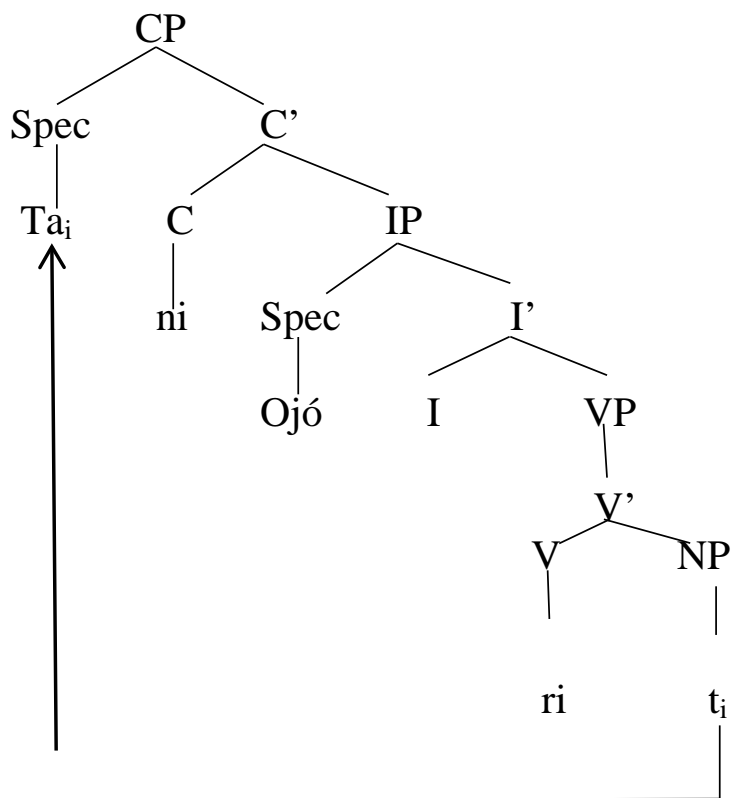

A close observation shows that the NP that was turned to a $\mathrm{WH}$ element is the item that was moved to the Spec-CP as in (16) above. This same process cannot be done for wo within the structure in which it appears. The reason is because wo cannot be the only element to which the whole PP or NP is turned to. In fact, there is no element within the structure that turned to wo. Consider the data below. We start the process from the underlying form of the clause used as interrogative sentence.

17
(a) Òjó dé ní alẹ àná
Òjó arrive Prep evening yesterday
Òjó arrived yesterday evening
(b) Òjó dé ní ìgbà wo?
Òjó arrive Prep period when
When did Òjó arrive?
(c) (N)ígbà wo $\mathrm{i}_{\mathrm{i}}$ ni Òjó dé $\mathrm{t}_{\mathrm{i}}$ ?
Prep period when FOC Òjó arrive
When $_{i}$ did Òjó arrive $t_{i}$

As can be observed in (17) above, the NP 'alẹ àná, 'yesterday evening' was first turned into igbà 'when' and wo is thereafter inserted ${ }^{41}$. The whole PP together with wo is then moved to the Spec CP through internal merge and to its landing site. It is obvious that there is no element

\footnotetext{
${ }^{41}$ The item wo is inserted so that the whole phrase can be turned to WH phrase. As will be shown, this wo has the feature WH within it which makes the whole PP or NP attracted to Spec-CP that has the feature WH to check.
} 
within the structure in (17) that turned to wo. It is also very obvious that the preposition ní can be dropped during movement without rendering the sentence ungrammatical. When the preposition moves together with the NP the process is known as pied-piping in the literature (we will say more on this below). Because there is no element that is turned to wo in (17), this is why it is ungrammatical to render (17a) and (17b) as (18a) and (18b) below.

18

(a) *Òjó dé ní wo?

Òjó arrive QM

Òjó arrived when?

(b) *Wo ni Òjó dé ní alẹ àná?

QM FOC Òjó arrive Prep. evening yesterday

*When did Òjó arrive yesterday evening?

The ungrammaticality in (18a) and (18b) is due to the fact that there is no element that turned to wo within the sentence. Besides, it shows that wo alone cannot be regarded as the (only) WH question marker/phrase in the structures in (17) and many like them. This goes to show that it is the whole PP adjunct that serves as question phrase and marks the structure as an interrogative sentence.

This same scenario is observed within a sentence where NP rather than the PP is the complement of the verb. We give examples by starting with the underlying clause.

19
(a) Adé ra ìwé
Adé buy book
Adé bought a book
(b) Ade ra ìwé wo?
Adé buy book QP
Ade bought which book?
(c) İwé $\mathrm{wo}_{\mathrm{i}}$ ni Adé rà $\mathrm{t}_{\mathrm{i}}$ ?
Book QP FOC Adé buy
Which book did Adé buy?

One important fact that manifested in (19) above is that wo which is designated as question particle (QP) is inserted in the position where it occurs. It did not originate from the underlying position. However, the insertion of this QP came up before Spell-Out for the sentence to converge at the level of the Phonetic Form (PF). The configurations in (20) and (21) below show the analyses of (17c) and (19c) above. 
20 Nígbà wo ni Òjó dé

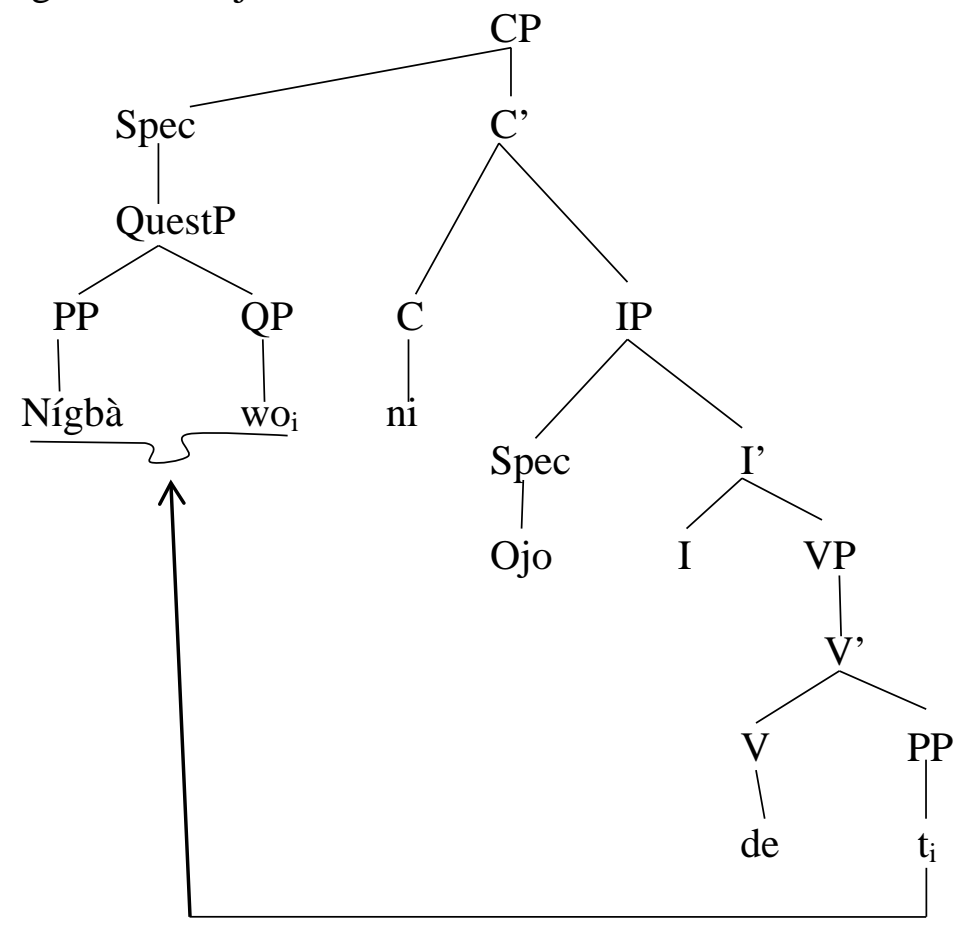

21 İwé wo ni Adé rà?

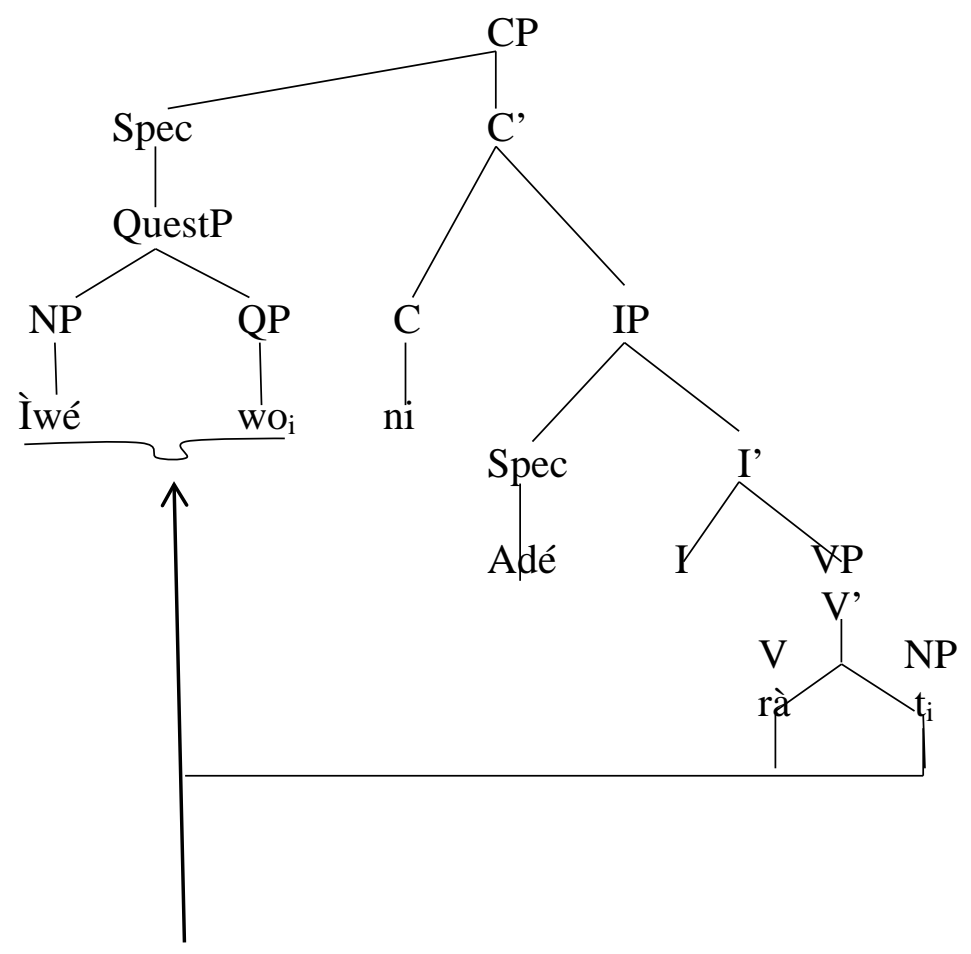


The two configurations in (20) and (21) show the analyses of the two types of structures where wo occurs.

Another issue to be resolved is 'at what point does the insertion of wo take place?' We posit that item wo is inserted before the internal merge of the $\mathrm{PP}^{42}$ or the $\mathrm{NP}$ as the case may be. This is done in order to turn the whole PP phrase or the NP phrase to an interrogative marker thereby serving as attraction for the Spec CP. There are two reasons for the insertion of this element. One, the Spec CP has a WH feature to check and except there is an item that has the feature $\mathrm{WH}$, the checking will not take place, hence the insertion of wo upon which this Spec CP can check its WH feature. Second, the interrogative sentence of this type cannot converge without the insertion of this quasi-WH item, hence, the insertion of wo before Spell-Out at the level of PF.

\section{The underlying form of wo}

In this section, we shall investigate the underlying form of this item wo. This question particle (QP), we believe is èwo in its basic form. The vowel $[e]$ at the initial position of the item normally gets deleted obligatorily in some environments within certain structures and optionally when it cooccurs with a Noun Phrase. When this item is rendered as ewo, it can be merged with an already existing clause by moving it to the Spec CP of such structure as shown in (22).

22

(a) Ėwo ni Olú ń wa ti?

QM FOC Olu PROG find

What $\mathrm{t}_{\mathrm{i}}$ is Olu looking for $\mathrm{t}_{\mathrm{i}}$ ?

(b) Èwo nínú wọn ní ó fẹ́ t $\mathrm{t}_{\mathrm{i}}$

QP Prep inside Pro FOC Pro want

Which of them do you want?

(c) İwé èwo $\mathrm{i}_{\mathrm{i}}$ ni Bọ́lá rà $\mathrm{t}_{\mathrm{i}}$ ?

Book QP FOC Bọ́lá buy

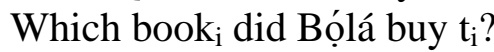

In (22a), the èwo is designated as question marker for the fact that in this instance, it is substituted for kí which is one of the question markers in

\footnotetext{
${ }^{42}$ We need to say at this point that the moved PP can be combined with any of the following NPs and even more:

Ní ìgbà wo ni Òjó dé?

Ní ojộ wo ni Òjó dé?

Ní ọ̀sè wo ni Òjó dé?

Ní ọdún wo ni Òjó dé

It is not the wo underlined that is the only question marker but the whole Prepositional Phrase (PP) or Noun phrase (NP).
} 
the Yorùbá language. In other words, the sentence can be rendered like (23) without any difference in meaning or resulting in ungrammaticality.

$23 \quad \mathrm{~K}_{\mathrm{i}}$ ni Olú ń wá $\mathrm{t}_{\mathrm{i}}$ ?

QM FOC Olú PROG find

What is Olú looking for?

However, the case of (22b) is different in that the NP that should follow it has been optionally deleted, hence èwo is designated here as question particle (QP). It is still grammatical because in the environment where the NP precedes, this QP can be used. This is evident in (22c) where both the NP and this QP were moved together to the Spec CP. However, it is not even common for the native speakers to utter the sentence in (22c) as rendered. But we cannot rule out the fact that some speakers can still utter it as rendered in the written form.

But the situation is different when the same QP occurs in the environment after a prepositional phrase. First, the vowel [e] deletes obligatorily. Second, the PP with which it co-occurs also obligatorily moves together with wo to the Spec CP. This is illustrated in (24) below.

$24 \quad$ Nígbà $\mathrm{wo}_{\mathrm{i}}$ ni Șadé sọ̀rò $\mathrm{t}_{\mathrm{i}}$ ?

Period QP FOC Șadé say word

When did Șadé speak?

It is therefore ungrammatical to render (24) in the form of structures in (25).

25

(a) *Nígbà èwo ${ }_{i}$ ni Șadé sọ̀rọ t ti ?

Period QP FOC Șadé say word

When did Șade speak $t_{i}$ ?

(b) *Èwo $\mathrm{i}_{\mathrm{i}}$ ni Șadé sọ̀rọ̀ $\mathrm{t}_{\mathrm{i}}$ ?

QP FOC Șadé sọ̀rọ̀ $t_{i}$ ?

When ${ }_{\mathrm{i}}$ did Șadé speak $\mathrm{t}_{\mathrm{i}}$ ?

The ungrammaticality in (25a) emanated as a result of retaining the vowel [e] of ewo which should have obligatorily deleted; while the ungrammaticality in (25b) is a result of moving only èwo which does not replace any item in the originating site to the Spec CP. The ungrammaticality is also due partly because there are no other items moved with èwo from the base position.

\section{Báwo as another phrasal WH question marker}

Apart from the question marker ...wo, there is one other question marker in Yorùbá which also makes use of ...wo; this question marker is báwo 'how'. Observing the question marker báwo very closely, there is no doubt that it is made up of two syllables - bí/bá and wo. Can we say it is the last part of this morpheme wo that is the sole question marker? The answer definitely will be NO. In using the marker, the two morphemes must be 
together before it can stand as a question marker - WH interrogative marker in this case. The example in (26) gives credence.

26 (a) Báwo ni ajá yìi șe kú?

QM FOC dog this Partc. die

How did this dog die?

(b) Báwo ni àwọn ọmọ wọ̀nyìi șe débí?

QM FOC Qty child these Partc. come here

How did these children arrive here?

(c) Báwo ni o șe mọ̀?

QM FOC 2sg Partc know

How do/did you know?

A close observation on the use of this marker shows that it can only be used with the verbal particle se. We posit that this verbal particle reflects the [+manner] feature inherent in this question marker báwo. Further research may bring out other facts connected with the use of this verbal particle.

Before moving to some other evidence on this issue of WH phrase, it is important to note that no matter the number of items that comes between the PP or NP within a structure, the whole phrase before the FOC marker has to be regarded as the question phrase. It is this whole phrase that marks the sentence as an interrogative one. We give example.

27 Irú ọmọ alákọrí burúkú $\mathrm{wo}_{\mathrm{i}}$ ni mo rán $\mathrm{t}_{\mathrm{i}}$ ní ișẹ́ yî́?

Type child incorrigible bad QP FOC 1sg send partc. work this

Which type of a bad incorrigible child did I send on this errand?

The originating site of the whole $\mathrm{WH}$ phrase is represented by $t_{i}$ and coindexed with the moved question phrase including wo which was inserted before movement.

\section{Evidence from some other languages}

The phenomenon of having a phrase instead of just an item as question marker at the Spec CP of interrogative sentence is not peculiar to Yorùbá language alone. There are other languages that manifest this same attribute. Consider the sentences in (28) below taken from the English language.

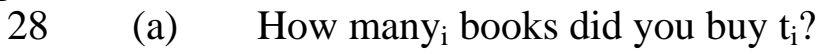

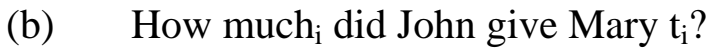

(c) Which book $\mathrm{k}_{\mathrm{i}}$ did Bill read $\mathrm{t}_{\mathrm{i}}$ ?

In (28) above, the how and which cannot be said to be the sole question markers in the sentences, it is the whole phrase that should be regarded as WH question phrase otherwise, the sentence will be ungrammatical (see 29a), (29b) and (29c). A speaker of English will agree 
that it is the combination of the two morphemes that is used to mark the sentences as interrogatives.

29
(a) *How books did you buy?
(b) *How did John give Mary?
(b) *which did Bill read?

Neither can many, much nor book be used independent of the how and which as WH markers or else, ungrammatical sentences as the ones in (30) below will be generated.

$30 \quad$ (a) *Many books did you buy?

(b) *Much did you give Mary?

(c) *Book did Bill read?

Therefore, before the sentences can be adjudged as grammatical, the two items must be moved together to the Spec CP and be designated as the WH phrase that marks the sentences as interrogative ones.

As reported in Akanbi (2014), Akrofi-Ansah (2010) explains that in Larteh, one of the languages spoken in Ghana, a Kwa of Benue Congo phylum uses a phrase, rather than a word, as a marker of WH interrogation when enquiry is being made about time or period. The sentence below (31), taken from Akanbi (2014:281) corroborates.

31 Bere fene te/manke ne a bè-yó sukuu?

Time how much in (time of day) FOC 3sg FUT-go school

When will he/she go to school?

(Akrofi Ansah 2010:104)

In her paper, Akrofi-Ansah also reports that languages like Akan, (Saah 1988, 2000) and Ga (Kotey, 2002) also uses phrase and not just single item as WH interrogative marker when eliciting information that has to do with time/period.

Of much relevance to this paper is the work of Cheng (1991) where he identifies languages like Bulgarian, Romanian, Polish, Serbo Croatian and Czech to name just a few where multi question markers are used as WH interrogative items. As explained by him (Cheng 1991), Rudin (1988) proposes that the fronted $\mathrm{WH}$-words in multiple fronting languages do not necessarily land in the same place. Rudin (ibid.) argues that the languages that manifest this type of interrogative markers are divided into two types: [+multiple filled Spec CP] languages and [-multiple filled Spec CP] languages. We believe that Yorùbá, in some instance, belongs to the first set of languages. The configurations in (32a) and (32b) represent the structural analysis of these two types of interrogative formations. 
32

(a)

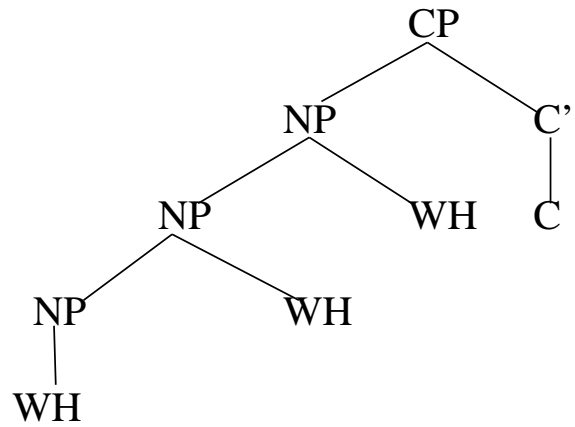

(b)

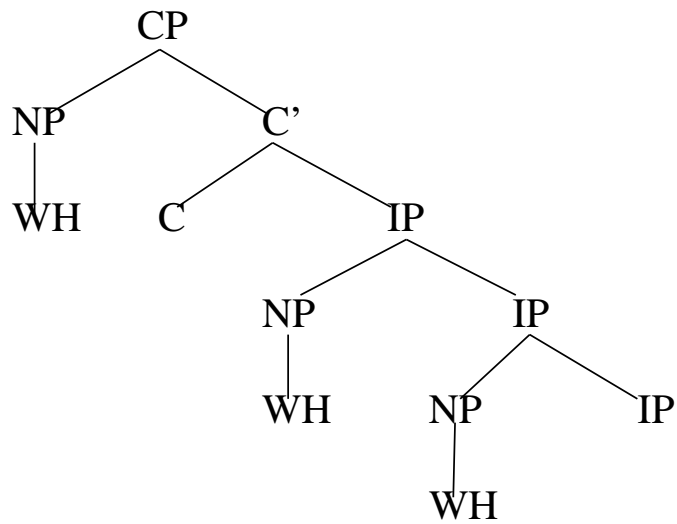

Cheng (1991) gives sentential examples for these two types of interrogative sentences that fall within those we have mentioned (interested readers are referred to Cheng 1991).

Following our arguments so far, we observe that Yorùbá language allows multiple adjunction to the Spec of CP in some instances. Besides, in structures where ...wo together with other elements are used as interrogative marker, allowance is giving for pied-piping while in some other uses of other interrogative markers, pied-piping is blocked. This informs why $\mathrm{WH}$ markers like ta 'who'; kí, 'what', and some others cannot be used within a pied-piping structure.

\section{Conclusion}

We have argued in this paper in support of the fact that Yorùbá uses multiple interrogative markers in certain environments in the formation of its interrogative sentences. We posit that the marker wo which is regarded as the item that marks the sentence as interrogative one in (33) below cannot be regarded as such; but that the whole phrase 'Nígbà wo' is the WH question phrase that marks the sentence as interrogative. 
Nigba wo ni Olú dé

Period QP FOC Olú arrive

When did Olú arrive/return?

Basing our arguments on series of examples, we posit that the item wo is inserted before the internal merge so that the sentence could converge. Not only this, since the Spec CP of such structures has WH feature, there is the need to check this feature against any WH element, hence the insertion of wo. This position is in line with Chomsky's (2000) assertion that 'movement must be triggered by a feature on a functional head'. This Chomsky's assertion is in tandem with the proposition of Rizzi (1997:282) taken from Newmeyer (n.d.:3) that "Syntactic movement ... must be triggered by the satisfaction of certain quasi-morphological requirements of heads. ... Such features have an interpretive import (Wh, Neg, Top, Foc, ...): they determine the interpretation of the category bearing them and of its immediate constituents ..." We therefore conclude that it is the wo within the sentence and the PP or the NP that give the interrogative marking, and that triggers movement to Spec CP hence, the whole phrase should be regarded as the WH interrogative marker/phrase.

To further buttress our position, some African, Asian and IndoEuropean languages that manifest multiple $\mathrm{WH}$ interrogative marking were alluded to and given as examples. There, we observe that the phenomenon found in Yorùbá also exists in the already mentioned languages used as examples in this paper.

\section{References:}

Akrofi-Ansah, Mercy 2010. Focused constituent interrogatives in Larteh. Nordic Journal of African Studies, 19(2); 98 - 107.

Ajíbóyè, Jacob O. 2005. Topics on Yorùbá nominal expressions. Ph.D. Thesis; The University of British Columbia, Canada.

Akanbi, Timothy A. 2014. A descriptive account of Àhàn verb phrase. Unpublished Ph.D. Thesis, Ekiti State University, Ado-Ekiti.

Awóbùlúyì, O. 2001. Arópò-orúkọ kúkúrú ẹnì kẹ́ta ẹyọ aṣolùwà. Yorùbá: Journal of the Yorùbá Studies Association, Vol. 2, No. 1; 1- 8.

Awóbùlúyì, O. 2006. 'Ó’ kì í șe arópò orúkọ nínú èdè Yorùbá. Yorùbá: Journal of the Yorùbá Association, Vol. 3, No. 3; 1 - 14.

Cheng, L. L. 1991. On the Typology of WH-Questions. Unpublished Ph.D. Dissertation. Massachusetts Institute of Technology.

Chomsky, Noam 1981. Lectures on Government and Binding. The Pisa Lectures. Dordrech: Foris.

Chomsky, Noam 1986. Barriers, Cambridge, MA: MIT Press.

Chomsky, Noam 1993. A Minimalist Program for language theory. In Kenneth Hale and Samuel J. Kayser (eds.). The view from Building 20. 
Essays in Linguistics in honour of Sylvain Bromberger. Cambridge, MA. MIT Press.

Chomsky, Noam 1995. The Minimalist Program. MIT Press, Cambridge, Mass.

Chomsky, Noam 1998. The Minimalist Inquiries: The Framework, MIT Occasional Papers in Linguistics, No 15.

Chomsky, Noam 2000. Minimalist Inquiries: The Framework. In Martin, R., D. Michaels, and J. Uruagereka (eds.). Step by Step: Essays on Minimalist Syntax in Honour of Howard Lasnik, MIT Press, Cambridge, MA; 89 - 155.

Ilori, Johnson F. and Francis. O. Oyebade. 2012. Negation in Igala. Entrepalavras, Fortaleza - ano 2, v.2, n.1, 25-40.

Kotey, C. 2002. Question formation in Ga. Unpublished M.Phil. dissertation, University of Ghana, Legon.

Newmeyer, Fredrick J. 2003b. Against the Split-CP Hypothesis. Generative Linguistics in Poland 5.

Newmeyer, Fredrick J. n.d. On Split-CPs, Uninterpretable Features, and the 'Perfectness' of Language. University of Washington, $1-23$.

Pollock, Joan Y. 1989. Verb Movement, Universal Grammar and the Structure of IP. Linguistic Inquiry 20, 365 - 424.

Rizzi, Lilian. 1997. The Fine Structure of the Left Periphery. In L. Haegeman, ed., Elements of Grammar: Handbook of Generative Syntax. Kluwer, Dordrecht, 281-337.

Rudin, S. 1988. Multiple filled Comp interrogatives. Ms.

Saah, K. K. 1988. Wh-question in Akan. Journal of West African Languages, 18(1); 17 - 28.

Saah, K. K. 2000. Interrogative sentence in Akan. University of Ghana/Utrecht Institute of Linguistics. Ms.

Sonaiya, R. 1988. WH-movement and proper government in Yorùbá. In Botne, R. and P. Newman (ed.) Current Approaches to African Linguistics, 5: $20-36$. 